Supporting Information for

\title{
Mechanically Robust 3D Nanostructure Chitosan-Based Hydrogels with Autonomic Self-Healing Properties
}

\author{
Ali Reza Karimi, ${ }^{* \dagger}$ Azam Khodadadi ${ }^{\dagger}$ \\ ${ }^{\dagger}$ Department of Chemistry, Faculty of Science, Arak University, Arak 38156-8-8349, Iran \\ *Corresponding author: a-karimi@araku.ac.ir
}


1. The synthesis procedure for zinc phthalocyanine tetra-aldehyde (ZnPcTa)

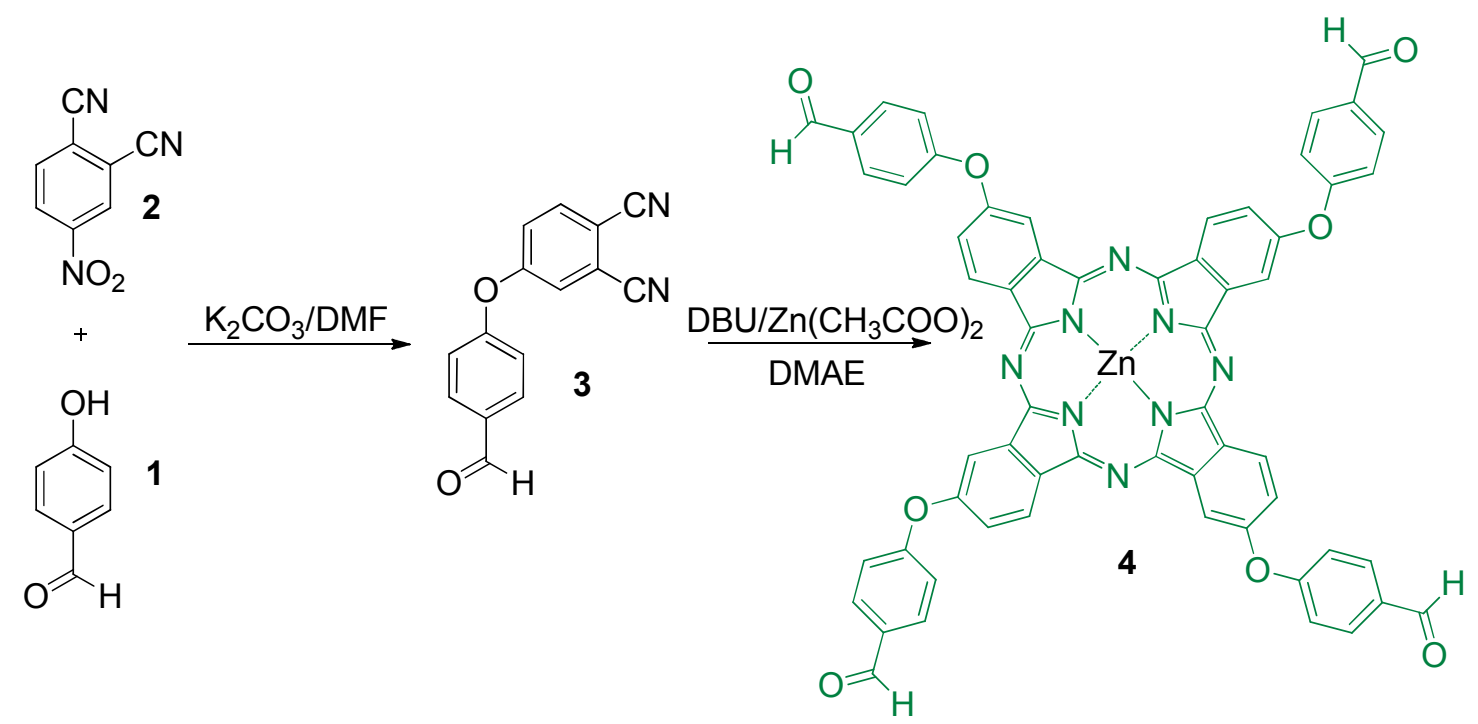

Figure S1. Synthesis of zinc phthalocyanine tetra-aldehyde (ZnPcTa)

\section{Additional analyses of cross-linker}

The IR spectrum of FPPht clearly indicate the presence of CN band. Figure $\mathbf{S 2}$ shows after cyclotetramerization of FPPht, the IR spectrum of phthalocyanine lacked the CN band, completely.

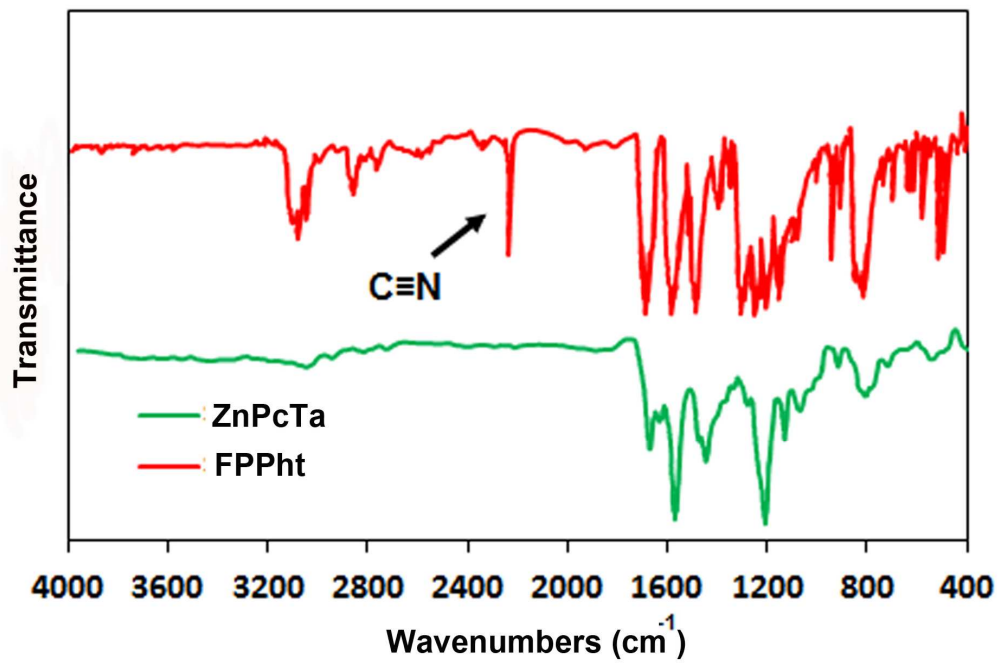

Figure S2. FT-IR spectra of FPPht and ZnPcTa

\section{Pore-size of hydrogels with different wt\% ZnPcTa.}

As shown in Figure S3, the ZnPcTa concentrations show very strong regulation on the pore size distribution of the hydrogels. 


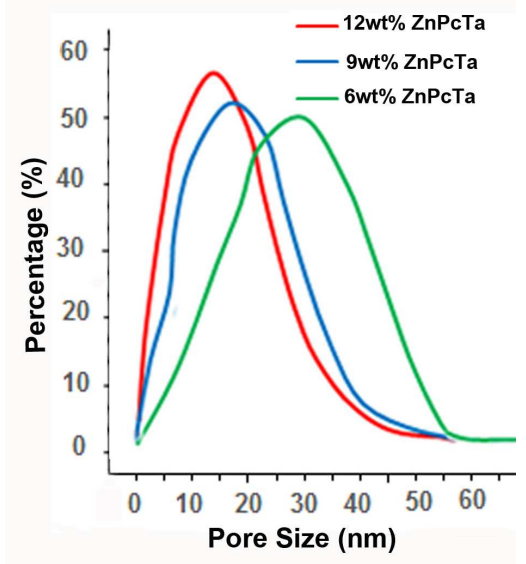

Figure S3. Pore-size distributions of the hydrogels with different wt $\% \mathrm{ZnPcTa}$

\section{Morphology of the non-functional MWCNT hydrogel nanocomposite.}

Scanning electron microscopy (SEM) analysis of the non-functional MWCNT exhibited aggregates of carbon nanotubes associated with hydrogel network.

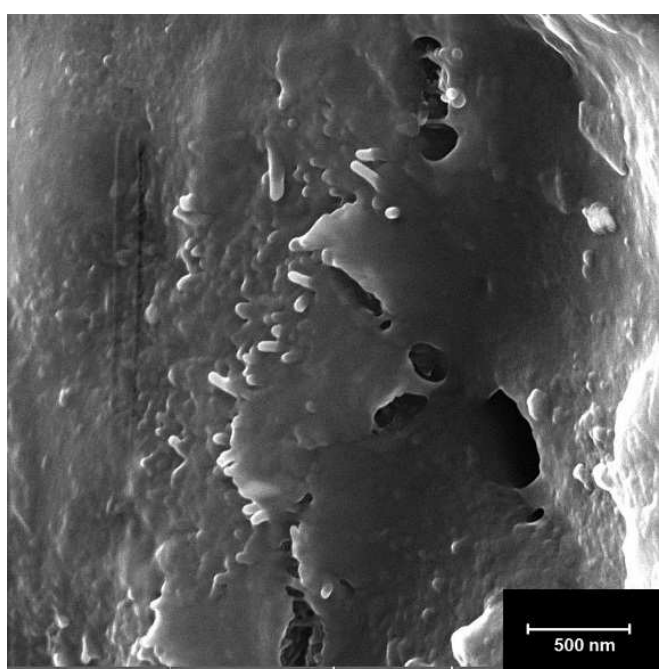

Figure S4. SEM image of hydrogel nanocomposite with $2 \mathrm{wt} \%$ non-functionalized MWCNTs

\section{Rheological analyses of hydrogels and hydrogel nanocomposites.}

The data of loss modulus $\left(\mathrm{G}^{\prime \prime}\right)$ versus frequency $(\omega)$ of hydrogels with different concetrain of $\mathrm{ZnPcTa}$ and hydrogel nanocomposites with the same concetrain of ZnPcTa and different MWCNT contents are shown in Figure S5- S6. 


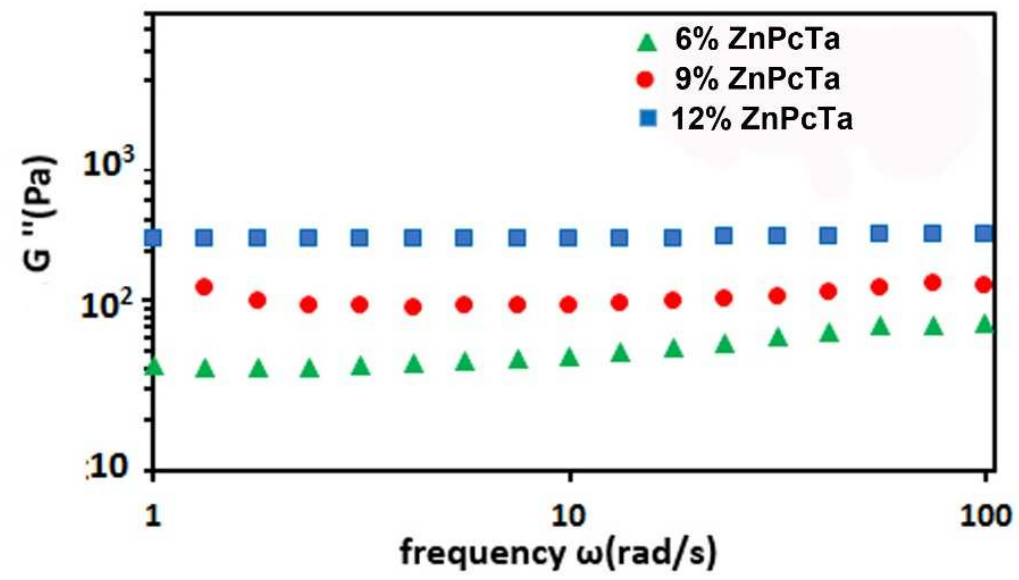

Figure S5. The loss modulus $\mathrm{G}^{\prime \prime}$ of the hydrogels with different $\mathrm{wt} \% \mathrm{ZnPcTa}$ at a fixed strain, $\gamma=5.0 \%$.

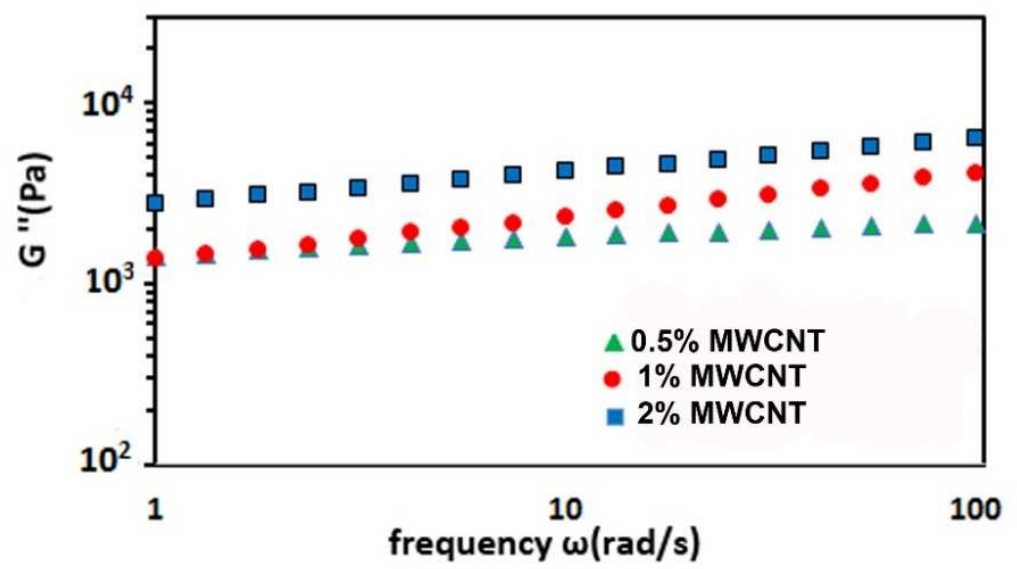

Figure S6. The loss modulus $\mathrm{G}^{\prime \prime}$ of the hydrogel nanocomposites with $12 \mathrm{wt} \% \mathrm{ZnPcTa}$ and different wt $\%$ MWCNTs at a fixed strain, $\gamma=5.0 \%$.

5. The effect of various wt\% MWCNTs on the healing rate of self-healing hydrogel nanocomposites.

As shown in Figure S7, the hydrogel nanocomposites prepared with $12 \mathrm{wt} \% \mathrm{ZnPcTa}$ and 0, 0.5, 1, and $2 \mathrm{wt} \%$ MWCNT, respectively, show healing time of $15 \mathrm{~min}(\mathrm{~m}), 18 \mathrm{~m}, 20 \mathrm{~m}$ and $30 \mathrm{~m}$, respectively. These observations are consistent with the previous report that the hydrogel nanocomposites with high $\mathrm{wt} \%$ MWCNT resulted in a slight decrease in recovery time. 


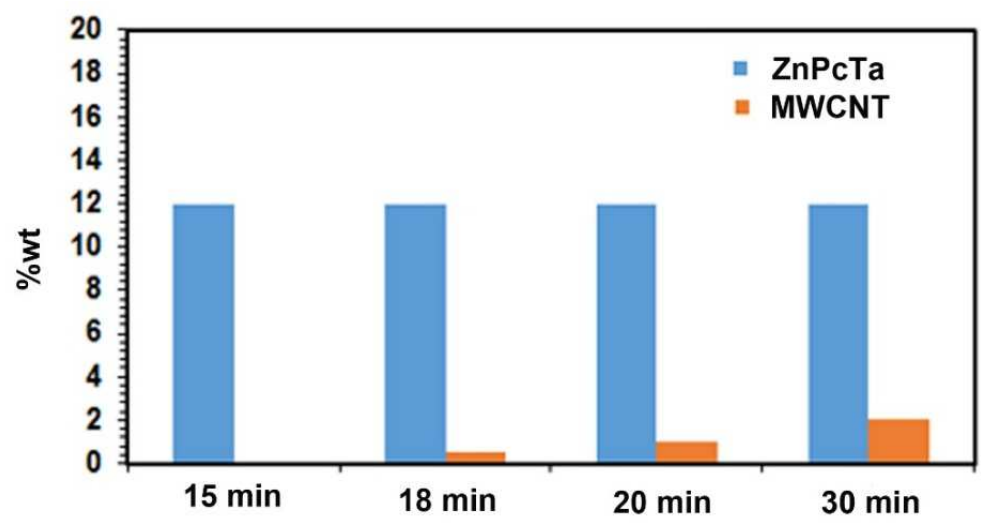

Figure S7. The effect of MWCNTs content on the healing rate of the hydrogel nanocomposites.

\section{Self-healing recovery and mechanical properties of some self-healing hydrogels based on dynamic covalent Schiff-base linkage.}

We investigate self-healing hydrogels with a focus on methods to test for the efficiencies of self-healing and recovery. This is followed by an explanation of the development of hydrogels that possess both selfhealing and robust mechanical properties.

Table S1. Self-healing recovery and mechanical properties of some self-healing chemical hydrogels.

\begin{tabular}{|c|c|c|c|c|c|}
\hline Polymer/materials & $\begin{array}{l}\text { Self-healing } \\
\text { mechanisms }\end{array}$ & $\begin{array}{c}\text { Healing } \\
\text { test }\end{array}$ & $\begin{array}{c}\text { Self- } \\
\text { recovery[\%] }\end{array}$ & $\begin{array}{c}\text { Mechanical } \\
\text { properties }\end{array}$ & Ref \\
\hline $\begin{array}{c}\text { Telechelic } \\
\text { difunctional } \\
\text { poly(ethylene } \\
\text { glycol) } \\
\text { (PEG), and chitosan }\end{array}$ & $\begin{array}{l}\text { Schiff base } \\
\text { (imine } \\
\text { linkage) }\end{array}$ & $2 \mathrm{~h}, \mathrm{RT}^{\text {a) }}$ & $\begin{array}{c}100 \%,<100 \mathrm{~s},(2 \\
\text { cycles of } \gamma=20 \% \\
\text { and } 200 \%, f=1 \\
\mathrm{~Hz})^{\mathrm{b})}\end{array}$ & $\approx 1150 \mathrm{~Pa}^{\mathrm{c})}$ & 1 \\
\hline $\begin{array}{c}\text { Telechelic } \\
\text { difunctional } \\
\text { poly(ethylene } \\
\text { glycol) } \\
\text { (PEG), and glycol } \\
\text { chitosan }\end{array}$ & $\begin{array}{c}\text { Schiff base } \\
\text { (imine } \\
\text { linkage) }\end{array}$ & $12 \mathrm{~h}, \mathrm{RT}^{\mathrm{a})}$ & $\begin{array}{c}100 \%,<10 \mathrm{~s},(3 \\
\text { cycles of } \gamma=1 \% \\
\text { and } 300 \%, f=1 \\
\mathrm{~Hz})^{\mathrm{b})}\end{array}$ & $\begin{array}{c}\sim 0.8 \mathrm{kPa} \text { at } \\
25^{\circ} \mathrm{C} \text { and } \\
\sim 1.5 \mathrm{kPa} \text { at } \\
37^{\circ} \mathrm{C}^{\mathrm{c})}\end{array}$ & 2 \\
\hline $\begin{array}{l}\text { Chondroitin sulfate } \\
\text { multiple aldehyde } \\
\text { and } \\
\text { N-succinyl-chitosan }\end{array}$ & $\begin{array}{c}\text { Schiff base } \\
\text { (imine } \\
\text { linkage) }\end{array}$ & $2 \mathrm{~h}, \mathrm{RT}^{\mathrm{a})}$ & - & $\approx 103 \mathrm{~Pa}^{\mathrm{c})}$ & 3 \\
\hline $\begin{array}{l}\text { zinc phthalocyanine } \\
\text { tetra-aldehyde } \\
(\mathrm{ZnPcTa})^{\mathrm{d})} \text {, and } \\
\text { chitosan }\end{array}$ & $\begin{array}{l}\text { Schiff base } \\
\text { (imine } \\
\text { linkage) }\end{array}$ & $\begin{array}{c}15 \mathrm{~min}, \\
\mathrm{RT}^{\mathrm{a})}\end{array}$ & $\begin{array}{c}100 \%,<100 \mathrm{~s},(3 \\
\text { cycles of } \\
\gamma=1 \%, 80 \%, \\
300 \%, 800 \% \\
f=1 \mathrm{~Hz})^{\mathrm{b})}\end{array}$ & $\begin{array}{c}\approx 2500 \mathrm{~Pa} \text { at } \\
25^{\circ} \mathrm{C}^{\mathrm{c})}\end{array}$ & - \\
\hline
\end{tabular}


a) Pieces of cut hydrogel rejoined, ${ }^{\text {b) }}$ alternative step strain deformation, ${ }^{\text {c) }}$ storage modulus $\mathrm{G}^{\prime}[\mathrm{Pa}],{ }^{\mathrm{d})}$ hydrogel with $12 \mathrm{wt} \% \mathrm{ZnPcTa}$.

7. The electrical conductance of self-repaired nanocomposites with $12 \mathrm{wt} \% \mathrm{ZnPcTa}$ and different MWCNT-COOH contents.

Table S2. Electrical healing for 3 cuts at the same severed location of nanocomposites with different MWCNT-COOH contents.

\begin{tabular}{ccccc}
\hline No. & $\begin{array}{c}\text { MWCNT- } \\
\text { COOH }(\mathbf{w t} \%)\end{array}$ & $\begin{array}{c}\text { Conductivity } \\
(\mathbf{S} / \mathbf{c m})^{\mathbf{b}}\end{array}$ & $\begin{array}{c}\text { Conductivity } \\
(\mathbf{S} / \mathbf{c m})^{\mathbf{c}}\end{array}$ & $\begin{array}{c}\text { Conductivity } \\
(\mathbf{S} / \mathbf{c m})^{\mathbf{d}}\end{array}$ \\
\hline $1^{\mathrm{a}}$ & - & $4.10 \times 10^{-6}$ & $4.06 \times 10^{-6}$ & $3.96 \times 10^{-6}$ \\
$2^{\mathrm{a}}$ & 0.5 & $2.95 \times 10^{-5}$ & $2.90 \times 10^{-5}$ & $2.87 \times 10^{-5}$ \\
$3^{\mathrm{a}}$ & 1 & $3.19 \times 10^{-4}$ & $3.16 \times 10^{-4}$ & $3.10 \times 10^{-4}$ \\
$4^{\mathrm{a}}$ & 2 & $2.92 \times 10^{-3}$ & $2.87 \times 10^{-3}$ & $2.85 \times 10^{-3}$ \\
\hline
\end{tabular}

${ }^{\mathrm{a}} 12 \mathrm{wt} \% \mathrm{ZnPcTa} ;{ }^{\mathrm{b}} 1$ st cutting-healing process; ${ }^{\mathrm{c}} 2$ st cutting-healing process; ${ }^{\mathrm{d}} 3$ st cutting-healing process.

\section{REFERENCES}

1. Y. Zhang, L. Tao, S. Li, Y. Wei, Synthesis of Multiresponsive and Dynamic Chitosan-Based Hydrogels for Controlled Release of Bioactive Molecules. Biomacromolecules 2011, 12, 2894.

2. T.-C. Tseng, L. Tao, F.-Y. Hsieh, Y. Wei, I.-M. Chiu, S. Hsu. An Injectable, Self-Healing Hydrogel to Repair the Central Nervous System. Adv. Mater. 2015, 27, 3518

3. S. Lü, C. Gao, X. Xu, X. Bai, H. Duan, N. Gao, C. Feng, Y. Xiong, M. Liu. Injectable and Self-Healing Carbohydrate-Based Hydrogel for Cell Encapsulation. ACS Appl. Mater. Interfaces 2015, 7, 13029. 